\title{
Article
}

\section{Rocking against patriarchy: Single-sex solutions for female musicians}

\author{
Gregory, Georgina
}

Available at http://clok.uclan.ac.uk/19407/

Gregory, Georgina ORCID: 0000-0002-7532-7484 (2017) Rocking against patriarchy: Single-sex solutions for female musicians. Journal of Popular Music Education, 1 (2). pp. 183-197. ISSN 2397-6721

It is advisable to refer to the publisher's version if you intend to cite from the work. http://dx.doi.org/10.1386/jpme.1.2.183_1

For more information about UCLan's research in this area go to http://www.uclan.ac.uk/researchgroups/ and search for < name of research Group>.

For information about Research generally at UCLan please go to http://www.uclan.ac.uk/research/

All outputs in CLoK are protected by Intellectual Property Rights law, including Copyright law. Copyright, IPR and Moral Rights for the works on this site are retained by the individual authors and/or other copyright owners. Terms and conditions for use of this material are defined in the policies page.

\section{CLoK}

Central Lancashire online Knowledge www.clok.uclan.ac.uk

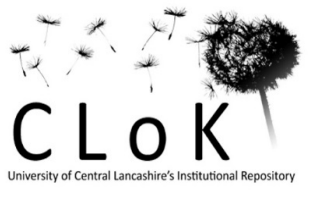




\section{Rocking against patriarchy: Single-sex solutions for female musicians}

\section{ABSTRACT}

Opinions on the merits of single sex education are divided, but it is acknowledged that this context for learning offers certain benefits for female musicians. This is particularly true for female rock guitarists and drummers, who are under-represented and rarely achieve virtuoso status. The scarcity of women musicians in rock and heavy metal is noted by various feminist scholars, but solutions to the problem of under-representation are elusive. In order to perform rock music professionally, women must develop initial musicianship skills. However, many girls and younger women report being intimidated, marginalized or excluded in rock bands, making it harder for them to gain experience. This article draws attention to two recent developments - female rock tributes and rock camps for women and girls - presenting them as offering a feminist solution for women who would like to perform metal and rock music with confidence.

\section{INTRODUCTION}

Opinion is divided on the benefits of single sex education (Jackson 2010; Harker 2000; Smythe 2010). ${ }^{1}$ To some observers, the practice may appear oldfashioned and against the current ethos of inclusivity. Nevertheless, when it

\section{KEYWORDS}

gender music

education rock camps tribute bands aspiring female musicians

1. In the United Kingdom, the term 'single sex' education is commonly used. It is acknowledged that the definition may present issues for those who reject gender binaries. 
comes to learning to play rock instruments and performing with peers, an all-female environment can help women overcome barriers to learning and performing (Abramo 2011). The article does not suggest that this is the only or even the best way to help women with learning, performing or to combat the under-representation of female musicians; rather that it is one way to redress the balance. The article is not the result of a systematic study of rock camps for women and girls or all-female tribute acts; instead, it highlights some of the experiences of women who have benefitted from these environments to demonstrate their potential. Comments from those involved in learning, teaching and performing in these spaces are used to show benefits that women can derive from working in this way.

Primary data were gathered from interviews with female artists on the United Kingdom's tribute entertainment scene as well as tutors and participants at rock camps. Their combined testimonies validate the value of learning alongside, working with or being taught by other women. In order to provide a broader context, the aforementioned data are related to secondary literature from the field of popular music studies and critical thinking on the value of separating girls and women from their male peers within education. Finally, I propose that further research on single sex learning environments might be given serious consideration because of the benefits it appears to offer aspiring female musicians.

\section{ROCK MUSIC: FOR EVERYONE OR STRICTLY FOR THE BOYS?}

An appreciation of the value of all-female learning and performance environments cannot occur without some awareness of the context of women's marginalization and under-representation in popular music (Björck 2010; Green 1997). During the 1970s when the rock genre was at its height, Steve Chapple and Rebee Garofalo wrote that,'Sexism is as pervasive in rock music as in any other form of music. It pervades the structure of the music industry as well as the lyrics and instrumentation of the music itself' (Chapple and Garofalo 1977: 269). Not only do women struggle to find employment in creative roles, they are all too often relegated to low-status administrative and support roles:

Most of the major labels - and indirectly, the independents - probably employ as many women as men, perhaps even more: 'tea ladies', secretaries, receptions, canteen staff, cleaners, and almost anyone servicing the needs of people within the industry will be female.

(Steward and Garratt 1984: 63)

Furthermore, the careers of female artists are typically controlled by men, a point highlighted by Keith Negus:

Most of the decisions about artists over the last thirty years have been made by men, and whilst there is no detailed research available on these decision-making processes, its consequences have been vividly illustrated by the portrayal of women in contemporary popular music.

(Negus 2001: 127)

During the 1970s, only four percent of the 100 top selling US albums were recorded by women (Champ 2004: 12). Their limited presence in the album 
charts has influenced their long-term stature as musicians, as Jacqueline Warwick explains: ${ }^{2}$

With the rise of AOR (album-oriented rock) in the late 60s and early 70s, and especially the phenomenon of 'concept albums' [...] albums began to be considered large-scale works of art, central to the notion of rock as serious, important and able to stand the test of time in the same way as classical music.

(Warwick 2007: 96)

Women's creative output was more likely to surface in the cheaper format of the single record. With a reduced presence in the rock album charts, they were taken less seriously as musicians by those responsible for marketing music most of whom prefer to present women as solo artists or as vocalists fronting male rock bands. This trend largely continues today, insofar as:

Female artists aren't marketed in groups like men. If they do happen to be in a band, its largely with other blokes in one of two forms: taking a sideline as the keyboard player, or as the entire focus of the band (sorry, 'the Machine', but it's all about Florence). There are exceptions to every rule but the solo female artist is a gold standard in the music industry. Whether we may be better off for it or not, there isn't a girl equivalent of U2, Coldplay, Radiohead or Kings of Leon.

(Iqbal 2010)

Women's achievements are also overlooked in mainstream platforms of the canon where, during an eighteen-year period, only three of the prestigious Mercury Prize winners were female. Similarly, in the Rock and Roll Hall of Fame's '500 songs that shaped popular music', only 35 feature the work of female artists. ${ }^{3}$

\section{Gendering the equipment}

The dilemma of under-representation in rock and metal is not helped by the gendering of instruments and equipment, both of which present barriers to female participation (Green 1997). Marion Leonard reminds us how,'particular musical instruments, music technologies and sounds have become associated with masculinity and femininity' (Leonard 2007: 96). Hence those attempting to take on the 'masculine' hardware of rock can experience an uncomfortable learning trajectory. For instance, Helene Stapinski, a drummer in the New York band Stephonic, explains how she was ridiculed for admitting to an interest in the drum kit: 'When I was in high school I would say I played the drums and the boys would laugh at me. It was sort of a joke' (Longrigg 2004).

The voice is similarly stereotyped along gender lines. In rock and metal, masculinity is upheld vocally, by avoiding 'pop' style singing because of its connotations of femininity. Although nervous shrieking and use of the higher falsetto register is a central aspect of (male) rock vocalization, any feminizing connotations are subdued within the contrast provided by gruffer, more 'manly' vocals and the harsher timbre and texture of much of the accompanying music. Even in higher education contexts where a greater degree of objectivity might be anticipated, the value of the female voice is often diminished (Smith 2015; Parkinson and Smith 2015). Influential cultural commentator Theodor Adorno

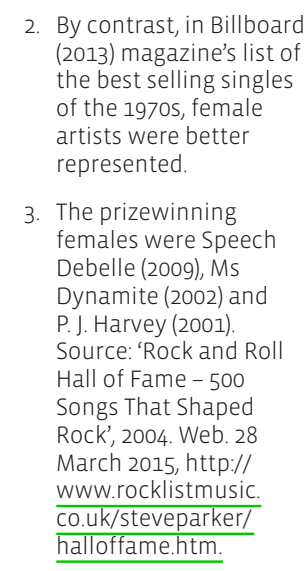


4. Some manufacturers (e.g. Luna) have responded to the need by supplying a range designed specifically for women. See http:// www.lunaguitars.com/.

5. An equalizer or 'EQ' enables precise control of the sound system. With $\mathrm{EQ}$, adjustments can be made that allow the performer to speak or sing at high volume without experiencing 'feedback' disparaged the inherent qualities of female vocalizing, suggesting that, 'Male voices can be reproduced better [in recordings] than female voices' and in his opinion, 'the female voice can easily sound shrill' (Adorno 1990: 54). Similarly Judith Baxter's (1999: xiv) findings on perception of the voice define the male public voice as competitive, ego-enhancing and hegemonic in comparison to the female variant.

\section{Technical and practical issues}

Taking the aforementioned observations into account, is it surprising that Hallam et al. (2008: 9) found girls are often reluctant to learn to play rock instruments? The scale of many instruments fails to match female proportions; the classic Dreadnought guitar shape, for example, is unwieldy for many women. ${ }^{4}$ Moreover, from a purely practical perspective, the majority of rock performance microphones are designed to accommodate the EQ range of the male voice and do not do justice to the subtleties of female vocalizing. ${ }^{5}$ Thus, when Whiteley (1997: 37) poses the rhetorical question, 'Where are all the great female electric guitarists?', rather than automatically assuming a female skills deficit in rock musicianship, we should look instead to feminist scholarly research for an answer.

It is not the case that women choose to accept their musical subjugation. Instead, Valerie Walkerdine argues, 'we are filled with roles and stereotypes of passive femininity', and moreover, 'femininity and masculinity are fictions linked to fantasies [...] which take on the status of fact when inscribed in the powerful practices like schooling, through which we are regulated' (Walkerdine 1990: xii). Amongst others, Bayton (1998), Björck (2010), Carson et al. (2004), Clawson (1999) and Cohen (1997) have demonstrated how at each stage, from song writing and rehearsal to recording and touring, women are confronted with obstacles. From the outset in childhood, boys are more likely to receive a guitar as a gift from parents, with only four percent being purchased for girls (Schou 2007).

Furthermore, trips to guitar shops can invite unwanted misogynistic or sexist treatment. According to singer songwriter Emily White, 'There were never any women working in them and still rarely are'. When she went on to work in a guitar shop, she found customers did not take her seriously, and writes, '[W] hether you're playing or recording or selling or buying, you always have to prove yourself' (White cited in Carson et al. 2015: 1). Seasoned guitarist, Melissa Bobbitt, explains how during her teenage years, when asking for a Fender Stratocaster, male employees invariably offered her a lighter Squire guitar or one from the girlier 'Daisy Rock' range. She also alludes to a shortage of female assistants with technical expertise, citing how:

At Guitar Centers [in] Pasadena and West Los Angeles the women either handle bag check at the entrance or ring up customers at the register. Nowhere have I seen a female tech, roaming salesperson or luthier at any Guitar Center in my two decades of shopping there.

(Bobbitt 2015)

For many women, it seems that 'processes of skill acquisition interact with the dynamic of early adolescent gender formation to produce an institution and an array of practices that can be termed masculine' (Clawson 1999: 99).

Citing Bourdieu's (2001) concept of 'masculine domination', Hebert et al. (2017: 458) note that this powerful societal force 'exerts and reinforces its 
power and normativity in popular music education (PME) through institutionalized processes, curricula, repertoire (canon) and other music industry norms, including the gendering of musical instruments'. As Parkinson and Smith (2015: 110) point out, 'to be authentically gendered in popular music is to be masculine', or is at least to be 'constructed' from the perspective of the heteronormative 'male gaze' (Lieb 2015). Furthermore, Cohen (1997: 81) observes how women playing rock are more likely to be valued for their looks than for their musicianship. As Helene Stapinski points out, 'When Led Zeppelin were playing, whoever said, "The drummer's really ugly?"' (Stapinski in Pearson 2014: xvii).

Women who learn or perform alongside men may find the experience intimidating (Abramo 2011), an experience that hinders the development of skills. This argument is endorsed in an Internet blog on the subject of female guitarists that features the following post:

Put two beginner guitarists together in a jam session, one male and one female. I can almost guarantee the male will try to dominate the session. Men have a natural instinct to overshadow females in the same activity [...] The female does not have the opportunity to do her thing, therefore putting her back, and making her feel insignificant in the session. This doesn't allow her to progress her skills, leaving her stranded on what to do next [...] Believe me, I've had that from constant experiences.

(NewRage 2008)

According to Cohen, other tactics employed by male musicians included sexual intimidation and isolation: 'In the everyday conversation of male band members women are often treated as objects of sexual desire, conquest, or derision, or linked with the domestic sphere of family and home' (1997: 22).

\section{‘Walk Like a Man': Rocking against the odds}

A limited number of women have achieved success by joining forces with female peers. For Fanny, the first all-female rock band to be signed to a major record label in 1969, playing live before thousands of fans was a major milestone in the annals of female rock performance. ${ }^{6}$ Another female rock group The Runaways, also enjoyed a strong fan following, likened at the time to Beatlemania. ${ }^{7}$ Moreover, these pioneering female bands did not simply imitate their male counterparts. For instance, American rock band, The Shaggs' unselfconscious ineptitude influenced subsequent grunge and punk artists, yet there are few references to the group in rock histories (Chusid 2000: 1). Likewise, many women played creative roles in the punk movement of the late 1970s, but these examples should not be viewed as symptomatic of gender equality (Green 1997). Indeed, it is argued that some of the manifestations of misogyny inherent in punk made feminism an easy target (Reynolds and Press 1995: 33).

More recently, the Riot Grrrl punk movement of the 1990s embraced feminist thought and activism in the creation of an underground, female-friendly music scene. Here, women were encouraged to represent their own interests, developing and exhibiting their musicianship skills without hindrance from male detractors. Riot Grrrl's contribution to dismantling the male canon is acknowledged by Downes (2012: 216), who claims the movement facilitated an emotionally charged music counterpublic, enabling women to claim cultural autonomy while challenging the status quo.
6. Fanny were signed to Reprise Records in 1969, they toured between 1969 and 1975 and released a number of hit albums and singles, www.fannyrocks.com/.

7. Source: Edgeplay A Film About The Runaways (2004) IMDB. 


\section{SINGLE SEX LEARNING: A WAY FORWARD?}

If women have the desire to learn how to play rock instruments without the hindrance of either misogyny or sexism, rock camps and all-female tribute bands appear to offer ways forward. In particular, these environments are likely to combat some of the educational issues, such as instruments and associated performance styles being designated as masculine or feminine, and the societal pressure to adhere to restrictive gendered norms (Abeles 2009; Abeles and Porter 1979; Hallam et al. 2008; Sinsabaugh 2005). As Estelle Jorgenson has outlined:

It is a commonplace that music and education are gendered in their historical tendency to exclude women and girls or marginalize them from the mainstream of musical life; to prescribe and proscribe certain musical activities for each gender; and to perpetuate white, male, heterosexual perspectives on music theory and practice in what counts for musical knowledge.

(Jorgenson 2008: 20)

These views are supported by research findings (Bergman 2009 cited in Björck 2010: 48) indicating that girls are less likely to opt for rock instruments at school or exhibit proficiency in performing when competent, due to a reluctance to 'show off' their skills. Girls are also less inclined to take part in more informal after school rock tuition where boys dominate because they dislike the masculinist atmosphere.

By eradicating the presence of male musicians and instructors, rock camps offer alternative environments where women may develop initial skills and exhibit them with greater confidence. By offering inclusive and safe spaces for women at either end of the learning spectrum, both rock camps and allfemale tributes provide tangible benefits that might inform the thinking of those charged with providing music education and training. Furthermore, the promotion of single sex education for girls has a sound pedagogic rationale. Jackson (2002) argues that both sexes benefit from separate education since their social and psychological development takes place at a different rate. Adding weight to the argument, Hughes (2006), Mael et al. (2005), Salomone (2003) and Sax (2011) suggest the benefits of single sex education are greater for girls. Moreover, Simmons and Blyth (1987: 153) observe that girls in single sex environments enjoy higher social connectedness and well-being than their female peers in mixed gender settings.

\section{Rock and roll boot camp}

Girls rock camps have been around for over sixteen years, following the opening of the first in Portland, Oregon. The United States is host to 44 camps, and the advisory board of the fundraising body Girls Rock Foundation includes a number of high profile artists including Beth Ditto, Kathleen Hanna and Tegan and Sara (Singh 2017). According to Girls Rock Camp Alliance, an organization devoted to promoting rock camps, there are at least 57 such camps worldwide (GRCA n.d.). As a single sex initiative, rock camps are enabling girls to overcome some of the barriers and transcend social structures discussed above. In the words of Vicky O'Neon, who set up the first UK camp in 2016, 'When I started out I didn't feel very confident in a male industry [...] Most female musicians have felt this way. I think if we can in some way help the 
next generation not to feel that, that's amazing' (Singh 2017). Her thoughts are echoed by those of a seasoned volunteer at Portland rock camp, who writes:

I do believe that rock camp helps [girls] overcome sexism in order to develop performance skills. The camp does this through pop-culture awareness and self-esteem building, letting girls know that it's OK to be loud and to fully express themselves. Girls are encouraged to take risks and fully supported when they do.

(Leslie Yeargers, e-mail to author, 5 March 2014)

Unhindered by male peers, girls can experiment and experience the freedom to learn unselfconsciously (Abramo 2011). Camps aim to challenge the learned passivity with styles of performance that may feel uncomfortable initially. In the words of one observer:

In some ways, Willie Mae [rock camp] is the opposite of charm school. It's more like a 'be strong' school, where part of the overall lesson is the one they hear in self-defence class. You don't have to be nice to everyone all the time. Don't be scared all the time either. Give the right nonverbal signals.

(Tillotson 2005)

In the words of Clementine, a professional drummer and founder member of Led Zeppelin tribute, Zeparella, 'Being nice is a pop music attitude' whereas 'Metal music is loud and aggressive'. She elaborates, 'When I play, I try to be as big and strong and monstrous as possible. But I am not trying to be a man, just trying to be as big and strong and monstrous as possible' (Clementine, personal communication, 3 March 2007). Clementine's attempts at nongendered musicking, however, might have been thwarted by the strong gendering of the drum kit - what Monson (1996: 66) identifies as 'cultural coding of the drum set as a masculine instrument requiring both physical strength and endurance'.

Although male volunteers are allowed to help in certain capacities, they are not employed as tutors because the effectiveness of the rock camp's pedagogic practice is amplified by the presence of female staff:

All of the band managers and instrument instructors are women.

Even our 'sound guy' is a gal. The emphasis is on allowing self-expression without judgment. What this does is allow the girls to actually open out without any painful retribution or taunting that so often occurs in our society.

(Pam Barrett, telephone interview, 24 March 2012)

With counselling, martial arts classes and sessions on positive body image available at many of the camps, girls confront and face their fears head on, allowing them to play unselfconsciously, with attitude and conviction:

I think rock camp is an amazing place for a woman to get introduced to a rock instrument that maybe she's always wanted to play since childhood but was told that 'girls don't play drums, electric guitar, or bass'. A woman gets to live out her dream of playing in or fronting a 
band without the negative messages she grew up with and with a ton of encouragement and support. She leaves the experience empowered, amazed, and quite possibly dedicated to studying the instrument she played at camp.

(Leslie Yeargers, e-mail to author, 5 March 2014)

Anecdotally, staff report that after camp, women continue with their mastery of an instrument, and the bonds formed can lead the formation of post-camp bands. Also the fast growth of rock camps in the US and beyond suggests that the longer-term benefits will eventually surface as more women and girls participate.

While the girls' rock camp clearly addresses some important issues in PME, the initiatives might be accused of failing to address the root problem of institutionalized sexism. It could also be argued that the move away from integrated gender tuition is a regressive step in cultures committed to stamping out gender inequalities. These arguments are countered by camp staff who see the exclusion of male participants and tutors as an essential step within a longer trajectory towards change. Indeed, a male volunteer at Portland rock camp offered the following defence:

The fact that no other male has volunteered during the four years I've been here is a testament to the necessity of Rock Camp. Many times I have thought, or heard from others, how great it would be if this camp weren't necessary; if girl bands and boy bands garnered equal respect in the musical community; if the genders mixed in music [and] if the differences were respected.

(Anderson et al. 2008: 151)

Elizabeth Venable, a camp tutor also defends the 'girls only' policy on similar grounds:

Because we can't click our heels and make sexism go away, organizations like The Rock ' $n$ ' Roll Camp for Girls are necessary. Rock camp gives girls and women support systems and opportunities they have historically been denied. By making knowledge and information accessible, and providing a safe space for girls and women, Rock Camp is a key element in bringing about necessary social change.

(Anderson et al. 2008: 151)

\section{IF YOU CAN'T BEAT THEM, JOIN THEM: PLAYING IN A FEMALE TRIBUTE BAND}

Although public performance opportunities are presented in-house at rock camps, if women want to exhibit their skills publically, they need to be able to go beyond the confines of the camp environment. Claiming a feminist space for women to explore and learn is not by itself sufficient. There are a number of reasons why this is the case. Cecilia Björck argues that, 'If the act of "claiming space" is thought of as simply being seen and being heard being "onstage" - without considering what comes before and after, we are mistakenly simplifying the act' (Björck 2010: 69). Women may wish to attract a paying audience or play for pleasure to an audience beyond the camp's supportive environment. 
In these circumstances, paying homage to classic male rock and metal bands is one solution to the dilemma. An analysis of leading entertainment industry website Tribute City (www.tributecity.com) indicates that there are 109 tributes to the iconic rock band AC/DC. By comparison, there are only two tributes to Joan Jett and none to either The Shaggs or Fanny. Launching a tribute is a risky activity, and musicians need to secure the largest possible fan base. As Coulangeon et al. (2005: 365) observe, female performers already command lower earnings and have less occupational stability. By performing 'men's rock', women can hope to redress the balance somewhat by securing employment because, as Fournet (2010: 20) reminds us, being female in a male-dominated field provides a unique selling point. At the time of writing, a search of Tribute City website reveals that amongst the growing legion of tributes to $\mathrm{AC} / \mathrm{DC}$, there are currently only five all-female ensembles: $\mathrm{AC} /$ Dshe, Girls Got Rhythm, Thunderstruck, Whole Lotta Rosies and Hell's Belles.

The efforts of female tribute artists serve to inspire others. In a website dedicated to bass playing, Wanda Ortiz of the Iron Maidens is described as'an inspiration to anyone who feels the bass is too big for them' (Burbridge, 2007). This inspirational perspective is echoed by Aja Kim, a former member of Iron Maidens:

I want to blow misconceptions out of the window and help other women see that for themselves and I do feel a sense of purpose in modelling behaviour that may perhaps help others give themselves permission to do the same. I always feel a strong connection to other women when I perform and the continued reaction is one of support. I know that seeing a physically powerful looking woman is really inspiring to other women.

(Aja Kim, e-mail to author, 24 October 2013)

According to Krenske and McKay (2000: 287), the forceful presence of men and the power relations on the scene have required women to 'do gender on men's terms', but if we use Burke's (1950: 227) classic concept of identification, it is easy to see how a deeper sense of female connection is forged through the gender role reversal of female tribute acts. Burke suggests connection can occur through a process of consubstantiation, whereby a fusion of the essence of each person enables them to transcend their uniqueness and difference. Assuming the identity and repertoire of male performers effectively disrupts and subverts conventional audience expectations at the rock concert, showing that loud and abrasive music is not inherently macho or exclusive to the masculine domain. In the words of one seasoned performer:

I think up until the last few years, music has been primarily a man's world so to speak. Women musicians were sort of a novelty [...] but that has changed tremendously in the last few years, and it's still changing. For spectators, I think some come to the shows out of curiosity, and some come out because they like to see a woman up there rocking like it's no one's business. There is an indescribable potency in that.

(Mandy Reed, e-mail to author, 28 October 2010)

Women's performance also opens up opportunities for alternative expressions of sexuality. For example, the AC/DC song 'Mistress for Christmas' fantasizes 
about impersonal sexual relations with anonymous, objectified women in lines such as

Easy come, easy go

Have a good time with lots of dough

Slippin' up high, slippin' down low

Love'em and leave'em, on with the show

Listen, I like female form in minimal dress

Money to spend with a capital ' $S$ '

Get a date with the woman in red

Wanna be in heaven with three in a bed.

(AC/DC 1990, 'Mistress for Christmas', Atco Records)

By re-presenting these lyrics, female artists create the 'gender trouble' identified by Butler (1990), who argues that rather than being a given, masculinity and femininity are sociocultural constructs, perpetuated through continual re-enactment. Hence the active and assertive presence of female tribute artists offers a corporeal challenge to the heteronormativity of rock music, as well as the subjugation of women more generally under patriarchy.

\section{Audience appeal}

From a commercial perspective, female tributes bands are able to attract more women to concerts; when asked who attended Iron Maidens gigs, the core audience was described as follows:

Mostly male ages $13-45$ but we are seeing a lot more women in the audiences and hope to see more. They're almost all hardcore Iron Maiden fans (or in the case of the kids, become fans after being exposed to this music) and are very accepting and appreciative of what we do. Things are really changing - and there are many, many more women who listen to hard rock and metal music today than when the music of Iron Maiden first became popular in the 1980s.

(Aja Kim, e-mail to author, 24 October 2010)

Some female fans feel sufficiently empowered to enter the area just below the stage, known as the 'mosh pit', where pushing, 'slamming' and aggressive shoving are ways in which male fans traditionally express their identification with the music. In the words of two Iron Maidens fans:

We don't normally risk going in there and getting, you know, touched up [...] but when we went to see The Maidens it was cool - nobody tried to touch me up or beat the crap out of us when we were moshing. It was just amazing - but without all that macho stuff going on. There was a frenzy going on in there but it was all about the music - not trying to show you can beat the hell out of everyone.

(Kayleigh and Rochelle, in person interview, 1 November 2015)

Aja Kim suggests that many of the male fans go to see the all-female bands primarily out of curiosity or doubt that women are capable of performing the music: 
We get a lot of people who can't believe women are playing this music and who have their doubts initially that we can pull it off. But once they experience our show the doubts dissolve and they completely accept and respect us, because they see and hear that we are serious musicians with serious chops who are also fans and love this music as much as they do.

(Aja Kim, e-mail to author, 24 October 2010)

It would be easy enough to criticize the women for performing another artists' work rather than their own, but many of the female musicians on the tribute scene are engaged in other projects such as original song writing, which they fit around their jobs and leisure pursuits as tribute artists. Finally, for anyone posing the question as to why, rather than writing their own music, the women choose to uphold the repertoire of the male pantheon, Leigh Westee, a member of the Kiss tribute Goddess of Thunder, responds as follows:

We get that a lot'why copy someone else's music? Why not create your own?' Well, our answer is, that this is a hobby [...] Sure, we could start our own band, in fact most of us ARE in original bands also, but the KISS tribute is SO much fun and so near and dear to our hearts that we'd never give it up! We never really thought about'Oh we're girls and KISS are guys so we can't do this'. We feel like we have the same right to show our love for KISS by forming a tribute band. And we do as much as any guy band would do, from costumes to fire breathing! We feel like we probably have to work twice as hard to prove ourselves and be taken seriously because we're girls.

(Leigh Westee, e-mail to author, 3 March 2012)

\section{CONCLUSION}

More research is clearly needed to establish long-term benefits as well as any negative consequences associated with single-sex music education. However, initial observations suggest that, at the very least, this style of learning provides girls and women with basic materials to gain sufficient confidence to perform rock and metal music. Although the key issues of gaining recognition and attracting an audience are only partially resolved, paying homage to the work of classic male artists allows women to gain respect for their musicianship - a situation that may appear counter-intuitive, as it somewhat contradicts the finds of other studies (e.g. Smith 2013: 145-46) that have found the dearth of female role models (and resulting reliance on male rock icons) to diminish women's credibility or confidence in the masculine domain. The ability of all-women groups to claim a stake, or to 'claim space' (Björck 2010) in the tribute entertainment scene makes them more appealing to many promoters. By subverting the hegemony of male virtuosity, new ways of experiencing rock music are provided, which challenge the conventions of gendered spectatorship and the assumption that only men can play 'men's' music. As full participants in the production of rock music, the single-sex solution allows women to enjoy the liberating experience of working alongside one another in a supportive and productive manner. 


\section{REFERENCES}

Abeles, H. F. (2009), 'Are musical instrument gender associations changing?', Journal of Research in Music Education, 57:2, pp. 127-39.

Abeles, H. F. and Porter, S. Y. (1979), 'So your daughter wants to be a drummer?', Music Educators Journal, 65:5, pp. 47-49.

Abramo, J. M. (2011), 'Gender differences of popular music production in secondary schools', Journal of Research in Music Education, 59:1, pp. 21-43.

Adorno, T. W. (1990), 'The curves of the needle', October, 55, pp. 48-55.

Anderson, M. and Sleater-Kinney, C. B. (2008), Rock ' $n$ ' Roll Camp for Girls, San Francisco, CA: Chronicle Books.

Baxter, J. (1999), 'Teaching girls to speak out: The female voice in public contexts', Language and Gender, 13:2, pp. 81-98.

Bayton, M. (1998), Frock Rock: Women Performing Popular Music, New York: Oxford University Press.

Billboard (2013), 'Hot 100 55th anniversary: Every no. 1 song (1958-2013)', http://www.billboard.com/articles/columns/chart-beat/5149230/hot100-55th-anniversary-every-no-1-song-1958-2013. Accessed 23 February 2017.

Björck, C. (2010), 'Claiming space: Discourses on gender, popular music, and social change', Ph.D. thesis, Gothenburg: University of Gothenburg.

Bobbitt, M. (2015), 'I tried dressing like a Tomboy vs. Ultra-feminine to see if guitar center employees would treat me differently', http://www.xojane. com/issues/misogyny-at-guitar-shops. Accessed 23 February 2017.

Bourdieu, P. (2001), Masculine Domination, Cambridge: Polity Press.

Burbridge, O. (2007) 'Bad ass bass players', http://www.theironmaidens.com/ news/articles/badassbassplayers.com__Wanda_Ortiz_0607.pdf. Accessed 3 May 2017.

Burke, K. (1950), A Rhetoric of Motives, New York: University of California Press.

Butler, J. (1990), Gender Trouble: Feminism and the Subversion of Identity, New York: Routledge.

Carson, M., Lewis, T., Shaw, S. M., Baumgardner, J. and Richards, A. (2004), Girls Rock!: Fifty Years of Women Making Music, United States: The University Press of Kentucky.

Champ, H. (2004), 100 Best Selling Albums of the '70s, New York: Barnes \& Noble Books.

Chapple, S. and Garafolo, R. (1977), Rock 'n' Roll is Here to Pay, Chicago: Nelson Hall.

Chusid, I. (2000), 'The Shaggs: Groove is in the heart', in I. Chusid (ed.), Songs in the Key of Z: The Curious World of Outsider Music, Chicago: Acapella, pp. 1-12.

Clawson, M. (1999), 'Masculinity and skill acquisition in the adolescent rock band', Popular Music, 18:1, pp. 99-114.

Cohen, S. (1997), 'Men making a scene: Rock music and the production of gender', in S. Whiteley (ed.), Sexing the Groove: Popular Music and Gender, London: Routledge, pp. 17-36.

Coulangeon, P., Ravet, H. and Roharik, I. (2005), 'Gender differentiated effect of time in performing arts professions: Musicians, actors and dancers in contemporary France', Poetics, 33:5-6, pp. 369-87.

Downes, J. (2012), 'The expansion of punk rock: Riot Grrrl challenges to gender power relations in British indie music subcultures', Women's Studies, 41:2 pp. 204-37. 
Fournet, A. (2010), 'Women rockers and the strategies of a minority position', Music and Arts in Action, 3:1, pp. 20-47.

GRCA (n.d.), 'History \& timeline', http://girlsrockcampalliance.org/about-2/ history- timeline/. Accessed 23 February 2017.

Green, L. (1997), Music, Gender, Education, Cambridge: Cambridge University Press.

Hallam, S., Rogers, L. and Creek, A. (2008), 'Gender differences in musical instrument choice', International Journal of Music Education, 26:1, pp. 7-19.

Halpern, D. (2011), 'The pseudoscience of single-sex schooling', Education Forum, 333:6050, pp. 1706-07.

Harker, R. (2000), 'Achievement, gender and the single-sex/coed debate', British Journal of Sociology of Education, 21:2, pp. 203-18.

Hebert, D., Abramo, J. and Smith, G. (2017), 'Epistemological and sociological issues in popular music education', in G. Smith, Z. Moir, M. Brennan, G. Rambarran and P. Kirkman (eds), The Routledge Research Companion to Popular Music Education, Abingdon: Routledge, pp. 451-71.

Hughes, T. (2006), 'The advantage of single-sex education', National Forum of Educational Administration and Supervision Journal, 23:2, pp. 5-15.

Iqbal, N. (2010), 'Are women really on top when it comes to the charts?', http://www.theguardian.com/music/musicblog/2010/mar/11/women-topcharts. Accessed 23 February 2017.

Jackson C. (2002), 'Can single-sex classes in co-educational schools enhance the learning experiences of girls and/or boys?', British Educational Research Journal, 28:1, pp. 37-49.

Jackson, J. (2010), 'Dangerous presumptions: How single-sex schooling reifies false notions of sex, gender, and sexuality', Gender and Education, 22:2, pp. 227-38.

Jorgenson, E. R. R. (2008), Transforming Music Education, Bloomington: Indiana University Press.

Krenske, L. and McKay, J. (2000), 'Hard and heavy: Gender and power in a heavy metal music subculture', Gender, Place and Culture, 7:3, pp. 287-304.

Leonard, M. (2007), Gender in the Music Industry: Rock, Discourse and Girl Power, Aldershot: Ashgate.

Lieb, K. (2015), 'Pop stars perform "gay" for the male gaze', in M. Banks, B. Cnor and V. Mayer (eds), Production Studies, the Sequel! Cultural Studies of Global Media Industries, New York: Routledge, pp. 59-72.

Longrigg, C. (2004), 'Not bad - for a girl', http://www.theguardian.com/ music/2004/jan/30/gender.popandrock. Accessed 23 February 2017.

Mael, F., Alonso, A., Gibson, D., Rogers, K. and Smith, M. (2005), Single-Sex Versus Coeducational Schooling: A Systematic Review, Washington: U.S. Department of Education.

Monson, I. (1996), Saying Something: Jazz Improvisation and Interaction, London: University of Chicago Press.

Negus, K. (2001), Producing Pop: Culture and Conflict in the Popular Music Industry, London: Arnold.

NewRage (2008), 'Female guitarists', http://straight-hate.blogspot. co.uk/2008/03/female-guitarists.html. Accessed 23 February 2017.

Parkinson, T. and Smith, G. D. (2015), 'Towards an epistemology of authenticity: Higher popular music education', Action, Criticism, and Theory for Music Education, 14:1, pp. 93-127.

Pearson, A. (2014), Women Drummers: A History From Rock and Jazz to Blues and Country, Lanham: Scarecrow. 
Reynolds, S. and Press, J. (1995), The Sex Revolts: Gender, Rebellion, and Rock ' $n$ ' Roll, Cambridge, MA: Harvard University Press.

Salomone, R. (2003), Same, Different, Equal: Rethinking Single-Sex Schooling, New Haven, CT: Yale University Press.

Sax, L. (2011), Girls on the Edge: The Four Factors Driving the New Crisis for Girls? Sexual Identity, New York: Basic Books.

Schou, S. (2007), 'Guitars made for girls answer a growing trend in guitar market', http://lubbockonline.com/stories/031607/ent_031607076.shtml\#. WK7SDm- LSUl. Accessed 23 February 2017.

Simmons, R. and Blyth, D. (1987), Moving Into Adolescence, New York: Aldine de Gruyter.

Singh, F. (2017), 'Girls rock: The all-female music camp taking a stand against sexism', https:/www.theguardian.com/music/2017/jan/03/girl-rock-campmusic-industry-sexism. Accessed 1 March 2017.

Sinsabaugh, K. (2005), 'Understanding students who cross over gender stereotypes in musical instrument selection', Ph.D. thesis, New York: Columbia University.

Smith, G. D. (2013), I Drum, Therefore I am: Being and Becoming a Drummer, Farnham: Ashgate.

(2015), 'Masculine domination and intersecting fields in privatesector popular music performance education in the UK', in P. Burnard, Y. Hofstander and J. Soderman (eds), Bourdieu and the Sociology of Music And Music Education, Farnham: Ashgate, pp. 61-78.

Smythe, E. (2010), 'Single-sex education: What does research tell us?', Revue Française de Pédagogie, 171, pp. 47-58.

Steward, S. and Garratt, S. (1984), Signed, Sealed, Delivered: True Life Stories of Women in Pop, London: Pluto.

Tillotson, K. (2005), 'Rock \& role models; on their summer vacation, these girls learned how to play well with others - and sing loud, wail on guitars and pound drums onstage in their very own rock bands', http://www. highbeam.com/doc/1G1-135623014.html. Accessed 23 February 2017.

Walkerdine, V. (1990), Schoolgirl Fictions, London: Verso.

Warwick, J. (2007), Girl Groups: Girl Culture: Popular Music and Identity in the 1960s, London: Routledge.

Whiteley, S. (1997), Sexing the Groove: Popular Music and Gender, London: Routledge.

\section{SUGGESTED CITATION}

Gregory, G. (2017), 'Rocking against patriarchy: Single-sex solutions for female musicians', Journal of Popular Music Education, 1:2, pp. 183-197, doi: 10.1386/jpme.1.2.183_1

\section{CONTRIBUTOR DETAILS}

Georgina Gregory is a senior lecturer in the Department of Humanities and Social Studies at University of Central Lancashire where she teaches modules on popular music studies. She is author of Send in the Clones: A Cultural Study of the Tribute Band (Equinox 2012) and Relocating Popular Music (Palgrave 2015). Georgina also works in a freelance capacity as a music researcher, collecting data on behalf of the UK Performing Rights Society. She is also a member of the award-winning gospel choir Manchester Inspirational Voices. Her research 
interests include tribute entertainment, gender and performance and the history of popular music in Manchester.

Contact: School of Humanities and Social Sciences, University of Central Lancashire, Preston, PR1 2HE, UK.

E-mail: ggregory@uclan.ac.uk

Georgina Gregory has asserted her right under the Copyright, Designs and Patents Act, 1988, to be identified as the author of this work in the format that was submitted to Intellect Ltd. 